\title{
Bruck on the Floor Sings as Quietly as Monk Plays
}

Her whites make him spin. Her name is written on her name tag, Marta, she carries a tray with a plate with two slices of gray bread and a small pat of butter. Tell me, Marta, Bruck says, shouldn't one stay sober on a day like this, and from the corners of his eyes he looks at her ass, who came up with such an ass, Bruck thinks, even in my wildest dreams I would not be able to think up such a great ass, Bruck thinks, and Marta walks by the bed and pulls the curtains closed although it only is seven at night. Now, Mister Bruck, Marta says and grabs his hip, let's take care of your sugar. On the Charité's seventh floor with westward facing windows, Bruck thinks, why is the lady closing the curtains when the sun is still lurking above the rooftops? And could the gray bread be a logistical error, isn't this all about sobriety? Marta checks the blood sugar level, Bruck is bored, he does not even feel the quick pinch anymore. Thinking the word "sober," Bruck thinks of the lobby of the Soho Grand Hotel after Helen's last exhibit in New York in 1996, black and white pictures and mineral water, hearing "sober" Bruck thinks of Berlin's Treptow Park, January 1992, the Spree River's frozen water and his puffing breath in clouds, how he ran through the East when nobody else did, only the craziest Americans, hearing "sober" Bruck also thinks of every second beer after the first, because this is when sobriety ends and bliss begins. This ass, Bruck thinks, is baroque, and thinking the word "baroque" Bruck certainly does not have two slices of gray bread in mind, served on a light gray tray with a small pat of butter. Marta fumbles with the instruments and grabs Bruck's hip again, he arches his back. Marta smells faintly of Helen's perfume, Bruck thinks and flexes his stomach muscles. What remains of my stomach muscles, Bruck thinks. Bruck always thinks of Helen, doesn't Marta look a little bit like Helen? This ass? We shouldn't worry, Mister Bruck, Marta says and her white and her ass make Bruck spin, we shouldn't worry, she says, here, we only serve light food on evenings before such operations.

When the door falls shut behind Marta, Bruck thinks, such operations, and looks down at himself. Under the blanket he can 
make out his foot, he can even move it. Tamm tamm tamm, Bruck hums and the leg and the foot are tapping the beat. Can one call an amputation an operation, Nurse Marta, Bruck asks himself, is that allowed? Doesn't one have to call this a severe life experience, Bruck asks himself and loudly laughs into his single room. A movie is playing on the television, most likely it is set in Rome. Bruck listens to his laughter disappear in the room. Bruck opens the nightstand, takes out a small bottle of sliwowitz and drinks. Sugar is sugar, Bruck thinks, and schnaps is schnaps. Since when is Rome a film stage? What is this movie called? Do you have to leave a city when it is degraded to a stage? In 1968, when the city was degraded to a mere stage, Bruck left Prague by foot. Bruck signed the Two Thousand Words manifesto, Helen and the children had already gone to Berlin, Bruck still threw two, maybe five stones and then heroically took ten, maybe even forty truncheon hits and ran out of the city in that dark August night. Dubçek Dubçek Dubçek! He took the blood in his face for a walk. Bruck waits a second and thinks, the curtains swallow every bit of the laughter and the sun sets behind them. But what would be more fitting for a severe life experience such as this, Bruck thinks and again looks down at himself. He moves his right leg and watches the blanket move. He does not feel any pain. Brucks wonders why that is, is it due to the pills? A severe life experience, Bruck thinks and quickly removes the blanket, the sun has to touch this one more time. He puts the sliwowitz back in the drawer. Thinking the word "sun," Bruck thinks of his desk in Prague on Široká street, 1954, the hoofbeats on the Jewish Quarter's cobblestones and the rattling of the mopeds. Hoofbeats! How the sun entered the room in slices, how perfect their angles were! How Helen looked out of the skylight in the mornings! How they made their two children looking out to the graveyard, Thelonious Monk playing on the phonograph. Helen's open mouth above him, how he wanted to see her come! How he felt his heart beating in his throat! Bruck laughs quietly, this time with his face only, with his stinging eyes, with his Jewish nose, with his Slavic lips.

Bruck sits on the corner of his bed, facing the Charité hospital curtains, the curtains glow orange in the Berlin sunset and Bruck gets up and starts walking. What a chuzpenik! Bruck thinks, laughs and slowly makes his way to the window along the hospital's chairs. Absolutely no pain, Bruck thinks, how strange. Multi-morbidity?, 
Bruck thinks, not with Franz Bruck! Not with me! How lithely and springily did Bruck jog on the banks of the Seine, how he ran on the East River, on the Moldau's banks, on the banks of the Spree! Not with supple Bruck, the most dangerous fist on the Lower East Side in 1942! When he reaches the curtain, Bruck grabs the coarse fabric while his left hand lets go of the chair. He stops and breathes deeply. High blood pressure, Bruck thinks, to hell with high blood pressure! Not with Bruck, the Bowery's fastest runner, not with weightlifter Bruck, not with 300-push-up Bruck! He pulls the curtain to the side and then feels his right leg quietly give in, his most dangerous fist emphatically clenching the curtain, then he himself quietly sliding to the floor-together with leg and curtain-in between the Charité hospital's chairs and the balcony door, in his ears the sound of the curtain hooks coming off. Bruck then lies on the floor and laughs loudly because the curtain that could swallow his laughter is now lying under him. It is good that nobody has seen him, Bruck thinks, because elegance is something completely different from this.

When the sun sets over Berlin and the only light remaining in the room is the television, Bruck suddenly remembers the name of the film, maybe it was Roman Holiday with Audrey Hepburn, whereupon Bruck thinks that Audrey Hepburn also had a sober face, but Roman Holiday is a typical Sunday afternoon movie, the door opens and Marta comes to pick up the tray. Bruck sees her legs on the other side of the bed, is she barefooted, is she really barefooted, Bruck asks himself. Are her legs really that clean-shaven? Marta really is barefooted, and here in the legendary Charité that is very likely an infraction against official regulations! But Bruck wants to overlook this because she really has beautiful feet, this lady, these toes, this nail polish! Marta, Nurse Marta, Bruck remarks, stands next to his bed in his single room and Bruck can see her toes! Marta stands there, switches off the television, and notices that Bruck and the curtain have disappeared. Marta switches on the bedside light and asks, Mister Bruck? But Bruck, very contented, lies on his back between bed, sofa set and window, feather-bedded on the curtain he quietly sings to himself. He sings "In My Solitude" as quietly as Thelonious Monk plays it. "In My Solitude"! Monk! Dadidadadi! Ellington! Hypercholesterolanaemic? Not with Franz Bruck, the impressive gentleman at the door of Minton's playhouse 1946! Not with Harlem's only white bouncer! Bruck beats the time, his leg 
beats the time when Marta hears the humming and discovers Bruck. Not with Franz Bruck, red-suited Mr. Brook with the feathered hat! But Mister Bruck, what are we doing here, Marta asks, pushes a button, rushes around the foot of the bed and puts her index finger to Bruck's wrist. Bruck inhales through his nose when Marta takes his head in her hands, he smells her perfume and her delicate, her very delicate sweat. Are we afraid, Mister Bruck, Marta asks, we don't need to be, no we don't, she whispers, a red light above the door glows into Bruck's single room, In my solitude, hums Bruck, in my solitude.

Marta kneels next to Bruck, Mister Bruck, she says, what shall we do with you? Is there a hint of rebuke in her voice? Her whites, her sweat and her ass make Bruck spin. These nails, this most delicate polish! Bruck feels his heart beating faster and Marta, now with her finger right below Bruck's chin, is getting nervous, too. Calm, calm, she says to Bruck and then louder and in the direction of the door, rush, rush! The red light goes out, the neon lights in Bruck's single room are turned on and blind Bruck, two men bend over him, their shoes are squeaking on the linoleum, one wearing green, the other one wearing white that calms Bruck down. CHD-patient, asks the white one and this is something that Bruck knows from his file: coronary heart disease. Maybe Marta nods with Bruck's head in her hands while the two men press a cold stethoscope on to Bruck and pump a cuff around his arm. CHD, Bruck thinks and feels his heart calm down, not with me! Not with horse-lunged Bruck who ran around the Karlshorst hippodrome in the winter of 1972, only to clear his head. At that time, nobody else ran like this! Bruck closes his eyes. A clear head for the books about Monk and Sonny Rollins, for his own books, for the children. How Helen rode her bicycle next to Bruck, how she sang! How his legs hurt! How Helen kicked the pedals, how Bruck gasped, how Bruck steamed in Helen's studio! How we made love on the living room floor! Nothing, the white man says and packs up the stethoscope. Let's move this up again, says the green one.

The two men pick Bruck up from the floor and bundle him into bed. They are stashing me away, Bruck suddenly thinks, but not with me, not with blue-eyed pickpocket Franz Bruck on Montmartre 1936, nobody can catch me, I run faster than any robbed man, I run faster than any policeman, I run faster than any German! Marta picks up 
the curtain, folds it and puts it on the chair. How he stole wallets for a week and then bought a cap and oranges. How those oranges tasted! How his father took the money, scolded him and called him off and laughed at the same time! Bruck watches the men put away his legs under the blanket and attach laquered metal railings to the bed on his left and right. Bruck closes his eyes. This is a skinny one, says one of them, this one's really light for his size. As I always say, says the other one, diabetes is no bowl of sweet cherries, to which the first one replies, this really is a lame joke! Not with me, Bruck thinks, not with shipmate Bruck in the Lisbon harbor 1939, the passports sewn in, his sister on the suitcase on the quay, their parents god knows where. The father was a fine man! How Bruck bought a stick of sweet rock for his sister to be finally quiet. How only on their second night on board they told him to play the violin, play, violin-boy, play! During the days, he had to help the cook, what boiling heat! Melt the grease, peel the potatoes, always with the same blunt knife! The polka! The waltz! Diabetes, Bruck thinks, I do not deserve this, the father has given this to me. The two men are still stashing away Bruck's legs, left or right, asks the first one and the second one answers, sooner or later both must go. Bruck thinks, are they talking about me? Are they laughing about me? Are they laughing about violin-boy Bruck on Sunday afternoons in Hotel Imperial? When father played the afternoon tea dances. The polka? The waltz? How violin-boy Bruck beat the rhythm of the music with his feet and felt the passing tram-cars in his legs, how he jumped on stage for the encore! The duet of father and son, both tapping, fiddling, whistling in sync! The violin-boy Bruck, the wunderkind Bruck, the coffee with milk and sugar as praise for seven-year-old Franz Bruck, on Prague Sundays in 1932! Sugar and violin from his father, the Jewish nose from his mother-what a legacy! The two men have put away his legs, done and gone in a flash, says the first one. Quiet, quiet, Marta says, Mister Bruck? Are you asleep? And Bruck opens his eyes, how on earth are you talking to me, goddamnit, he asks, god damn it!

The men are leaving Bruck's room. Their shoes are squeaking on the linoleum. Marta takes the curtain from the chair and puts it on the table. From the corners of his eyes, Bruck looks at Marta and thinks of Helen, Bruck thinks of Helen and of Helen's ass so very often, because her ass not only made him spin, Bruck wants to say, 
her ass was a whole revolution, but Marta bends over him, Mister Bruck, are we panicking? Do we want to sleep? Or don't we? Helen in New York, Helen in Prague, Helen in Berlin. How they took walks, how they jogged, how they ran! And Bruck opens his mouth and takes the pills that Marta offers. In his mouth, Bruck plays with the pills, they taste sweet, they taste glazed! Bruck looks down at himself and moves his leg. His leg, his foot, the sand between the toes on the rivers, the splinters in his feet on the planks, the blisters in his shoes in the cities, the miles he walked, the beats he tapped, the stairs he climbed, his socks full of holes, his leather boots! Bruck moves his leg and his foot moves as well, his gangrenous toe, his gangrenous leg, his gangrenous thigh, Brucks thinks, done and gone! Bruck is relieved. Is that his chutzpah? Are these the pills? Don't be afraid, Mister Bruck, Marta says and hands him a glass of water, such an operation is by far the fastest operation of all, Marta says, touches his shoulder and leaves Bruck's single room above the roofs of Berlin. And Bruck takes another mouthful of sliwowitz, closes the drawer and hums "In My Solitude," like Monk, like Ellington, like Helen, like in those days, like always, like Bruck.

Translated from the German by the author, with Erin Edmison 